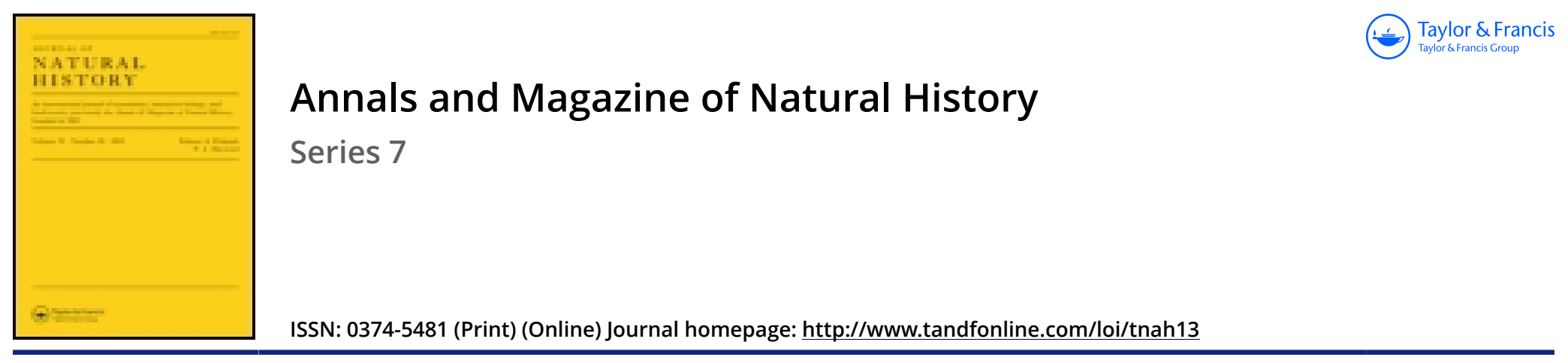

\title{
LXI.-Descriptions of new genera and species of New Zealand Coleoptera
}

\section{Capt. T. Broun F.E.S.}

To cite this article: Capt. T. Broun F.E.S. (1903) LXI._-Descriptions of new genera and species of New Zealand Coleoptera , Annals and Magazine of Natural History, 11:65, 450-458, DOI: $10.1080 / 00222930308678798$

To link to this article: http://dx.doi.org/10.1080/00222930308678798

曲 Published online: 29 Sep 2009.

Submit your article to this journal $\sqsubset x$

ЏII Article views: 4

Q View related articles $₫$

4 Citing articles: 1 View citing articles 진 
Fig. 2. Plistobunus rapax, gen. et sp. n. Lateral view of scute, anterior three free terga, mavdible, and palpus, the latter with tarsus and claw ornitted.

Fig. 3. Podactis pictulus, sp. n. Lateral view of scute and anterior three free tergal plates.

Fig. 3 a. Ditto. Ocular tubercle from the front.

\section{LXI.-Descriptions of new Genera and Species of New Zealand Coleoptera. By Capt. 'T. Broun, F.E.S.}

Group Cnemacanthidas.

Mecodema costellum.

- intricatum.

_- nitidum.

- variolosum.

Metaglymma rugiceps.

calcaratum.

Group ANCHOMENID A.

Dichrochile cordicolle.

Anchomenus Walkeri.

Tarastethus simplex.

- lævicollis.

\section{Group Feronitdx.}

Trichosternus Walkeri.

- akaroensis.

- bucolicus.

Pterostichus Kirkianus.

- memes.

- prasignis.

- setiventris.

Group HaRPaLID

Allocinopus sculpticollis.

Group Pogonddas.

Ö̈pterus latipennis.

- probus.

- parvulus.

Group Bembidind as.

Piembidjum actuarium.

Group Primicalid a.

Scopodes viridis.

Group HyDROPHILID_A.

Rygmodus nigripennis.
Cylomissus glabratus.

Zeadulopus spinipes.

Group Oxytelid

Troguphlœus maritimus.

Group Lucanid z.

Lissotes auriculatus.

Mitophyllus comognathus.

Group Pycnomerida.

Pycnomerus nitiventris.

Botbrideres picipes.

Group Opatrida.

Syrphetodes simplex.

\section{Group OEdFMrRid}

Thelyphassa fuscata.

Techmessa longicullis.

Exocalopus antennalis.

Group OtIoRHyNCHID $A$.

Cecyropa lineifera

- striata.

Brachyolus albescens.

- cervalis.

Aphela pictipes.

Group Cylindrorhinite.

Anagotus pallescens.

Sargon carinatus.

Group Rhrparosomide.

Memes rufirostris. 
Group Erirhinida.

Xerostygnus binodulus.

Stephanorhynchus pygmeus.

\section{Group Chrambycidie.}

Drototelus politus.
Group Lamind $x$.

Hybolasius cognatus.

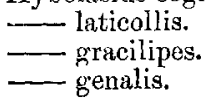

Group Cryptocephalid a.

Eualema Walkeri.

\section{Group Cnemacanthidæ.}

\section{Mecodema costellum, sp. n.}

Robust; head and thorax shining black, elytra rather dull, legs and antennæ nigro-piceous.

Head smooth on the middle, with longitudinal rugr in front and near the eyes; behind these there are numerous moderately small punctures. Mandibles unusually prominent. Eyes moderately distant from thorax, rather smali, their orbits swollen. Antennce pubescent from the fifth joint onwards, second joint as long as third. Thorax $4 \frac{1}{2}$ lines in width by $3 \frac{3}{4}$ in length, widest near the front, rather gradually narrowed backwards, but contracted to $2 \frac{3}{4}$ lines at the base; lateral margins only feebly crenulate; disk with slightly impressed transverse striæ; these, however, become more distinct towards the sides; the dorsal longitudinal groove is well marked, it does not attain the base or apex, but is almost foveiform at the extremities; the basal region bears short longitudinal striæ, and the fossæ are moderately large and close to the sides; just before the middle there is a punctiform impression near each side. Elytra oblong-oval, narrower at the shoulders than elsewhere; each with three slightly raised discoidal costr, the central one somewhat abbreviated, the first and third united near the apex; interstices more or less rugosely but not coarsely punctated, the sides with rather coarser sculpture.

Underside almost smooth.

J. Length 17 , breadth $5 \frac{1}{4}$ lines.

Described from a specimen forwarded by Captain F. W. Hutton.

$H a b$. Stephen's Island.

\section{Mecodema intricatum, sp. n.}

Elongate; brilliant black, the antennæ, tibiæ, and tarsi only slightly rufescent.

Head longitudinally rugose near the eyes and in front, vertex transversely rugose, the occiput with rugosely punctiform sculpture. Antennee reaching backwards to base of 
thorax; basal four joints glabrous, the others pubescent. Eyes prominent. Thorax of nearly equal length and breadth, apex slightly incurved, base feebly emarginate, lateral margins crenulate and hispid; it is widest near the middle and more or less abruptly constricted towards the base; the basal fossæ and central longitudinal groove are well marked; the transverse linear sculpture of its surface is most obvious near the sides, the basal and apical impressions are longitudinal. Elytra elongate, oviform; sutural region nearly plane and feebly strigose, the other portions are without regular striæ or serial punctures and appear as if covered with much interrupted costæ or catenulate sculpture.

Legs moderately slender, anterior tibiæ slightly produced.

Underside glossy pitchy black; the sides of the head and flanks of prosternum densely rugose; abdomen more finely sculptured, with transverse linear impressions on the terminal segments.

'The species may be readily recognized by the very irregular, almost chain-like sculpture of the elytra.

Length $11-13$, breadth nearly $3 \frac{1}{2}$ lines.

Te Oneroa, west coast of Otago.

Three examples kindly forwarded by Mr. P. Seymour.

\section{Mecodema nitidum, sp. n.}

Elongate; brilliant pitchy black; the terminal articulations of the antenna, the basal portions of the joints of the posterior tarsi, and the claws rulescent.

Head with coarse rugæ, chiefly longitudinal, the sculpture behind the eyes almost punctiform. Eyes small but prominent. Thorax very nearly as long as broad (2 lines), its sides rounded, abruptly contracted at the base, lateral margins crenulate; the disk bears transverse striæ which are deepest towards the sides; near the deeply impressed dorsal groove these striæ seem irregular, owing to the presence of short oblique or longitudinal striæ; near the front and base the rugæ are longitudinal, the basal foveæ are deep, close to each side, but more distant from the hind margin; this last and the apex are incurved. Elytra elongate, oval, their sculpture well marked, consisting of series of punctiform impressions; the two series nearest to each side of the suture are elongated and rather irregular, the third and fourth are deeper, evidently larger and distinctly longer; those nearer the sides are also deep, but many are of quite rounded outline.

Tarsi setose, the basal three joints of the anterior prolonged at the outer extremity. The middle tibia rather more asperate and setose externally than the posterior. 
Underside shining, the sternum more or less finely punctate.

This species most nearly approaches the $M$. rugiceps, Sharp, but is differentiated therefrom by its smaller size, glossy surface, disparities of sculpture, and emarginated base of thorax.

W. Length $7 \frac{1}{2}$, breadth $2 \frac{1}{4}$ lines.

Westport.

Mr. J. J. Walker, F.L.S., of H.M.S. 'Ringarooma' a well-known European entomologist, who discovered this species, also found a specimen of $\boldsymbol{M}$. metallicum, which he kindly placed at my disposal.

\section{Mecodema variolosum, sp. $\mathrm{n}$.}

Body slightly convex, brilliant fuscous black; legs, antennw, and palpi rufo-piceous, these last more rufescent.

Head rather short, nearly as broad as the thorax, its hinder portion distinctly but not closely punctured; the vertex nearly smooth, near the eyes it is irregularly and coarsely rugose, but on the epistome and labrum the rugæ are longitudinal. Eyes but little prominent. Antennoe pubescent from the fifth joint onwards, their fourth joint rather shorter than the contiguous ones; they reach backwards as far as the thoracic fossæ. Thorax 3 lines long by $3 \frac{1}{2}$ broad, its sides evidently crenulate, only gently rounded, but abruptly contracted behind, this narrowed portion parallel-sided, with rectangular angles; apex widely incurved, the base medially emarginate; the median furrow is entire and rather broad, so that the middle seems slightly depressed lengthways; the basal fossæe are large and placed close to the lateral margins, the disk is rather finely wrinkled transversely, the sides coarsely so; the base and apex are scored with short longitudinal rugæ. Elytra oblong-oval, their widest part scarcely exceeds that of the thorax; their lateral sculpture is very coarse and irregular; on each side of the suture there are two series of elongate impressions, which, however, can hardly be termed punctures, but form furrows near the base; the apical sculpture is also irregular and the whole surface is more or less marked by aciculate impressions.

There are eight or nine setæ along each side of the thorax, several on the elytra, four setigerous punctures on the labrum, and four at the extremity of the last ventral segment.

Underside black, shining; the head with dense zigzag sculpture; flanks of prosternum closely punctate-rugose; abdomen nearly smooth, but punctate near the base.

Anterior tarsi with the four basal joints dilated, the first two somewhat prolonged at the outer angles. 
At first sight I thought this might be Redtenbacher's $M$. crenaticolle. The head, however, is not elongate and narrow and the underside is far from being smooth. The head of Castelnau's $M$. crenicolle is simply rugose and the back part seems to be impunctate. A specimen of $M$. lineatum found by me at Tuakau agrees better with Redtenbacher's description, but it has the same close undulating sculpture on the lower surface of the head that is seen in $M$. variolosum.

$\delta$. Length 12 , breadth $3 \frac{3}{4}$ lines.

Rotorua.

A single individual, given to me by Mr. J. J. Walker.

\section{Metaglymma rugiceps, sp. $\mathrm{n}$.}

Subopaque, piceous black; antennæ and tarsi pitchy red, palpi paler.

Head with coarse longitudinal rugæ near the eyes and finer intervening transverse ones. Eyes convex, distant from thorax. Antenno almost nude, there being only a little fine pubescence on the three or four terminal joints. Thorax $1 \frac{3}{4}$ lines long, $2 \frac{1}{4}$ broad; the lateral curvature is slight, but near the base the contraction, though considerable, is not very abrupt; the hind angles are obtuse, the base and apex subtruncate; the disk bears numerous transverse striolæ, which become deeper towards the sides; at the base there are short, irregular, longitudinal striæ ; the fossæ are large and somewhat oblique, the dorsal furrow does not attain the front, and the lateral margins are a little explanate and feebly crenulate. Elytra ovate-oblong, broader behind than they are elsewhere, shoulders rather narrow; they are deeply punctate-striate, the interstices nearest the sides are distinctly narrower than those near the suture, apical sculpture coarsely punctiform or rugose. Tibice asperate, the outer angles of the anterior strongly produced, the intermediate moderately, the posterior scarcely at all. Tarsi setose, the basal two articulations of the front pair considerably prolonged exterually, the third less so, yet more distinctly than the fourth.

Abdomen smooth at the base, the last segment transversely strigose and bearing two setigerous punctures on each side of the middle at its apex, the intermediate segments with a transverse series of similar punctures on each.

M. tersatum is most like this species, but the sculpture of the head and thorax is quite different, and in $M$. rugiceps the joints of the firont tarsi are more evidently prolonged.

$\sigma$. Length $7 \frac{1}{2}$, breadth $2 \frac{1}{2}$ lines.

Albury (Mr. J. H. Lewis). One example. 


\section{Metaglymma calcaratum, sp. n.}

Shining, rufo-piceous; legs, antennæ, and palpi pitchy red. Head smooth. Eyes prominent, distant from thorax. Mandibles elongate, distinctly punctured above, rugose near the base. Antennce nearly glabrous, having only a little pubescence on the last four joints. Thorax $2 \frac{1}{8}$ lines in breadth by $1 \frac{3}{4}$ in length; apex arcuate-emarginate, slightly wider before the middle than it is elsewhere ; its sides, however, are apparently gradually narrowed backwards; lateral margins somewhat explanate from the rounded front angles to within a short distance of the base, where they form quite a thin edge; the base is slightly emarginate in the middle, but rounded towards the sides, so that the posterior angles are obsolete; basal fossæ rather large, median groove abbreviated. Elytra oval, rather broader than the thorax, shoulders rather narrow, distinctly punctate-striate; posterior sculpture irregular and intermingled with several setigerous punctures, of which there are also three on the seventh interstices.

Tibia moderately asperate, the anterior somewhat explanate along the outer edge and prolonged at the extremity; the inner calcar is long and extends as far as the apex of the third tarsal joint; intermediate also prolonged outwardly, the posterior less so; the two spurs on each of the hinder pairs are elongate. Tarsi setose, their basal articulations but little angulate.

Underside piceo-rufous; basal abdominal segment with two pairs of setigerous punctures, the second and third with a transverse series on each, the terminal transversely strigose and with a single puncture on each side of the middle at its apex.

This species should be located next to $M$. modicum, but the shape of the thorax, the general sculpture, the development of the tibial spurs, and antennal pubescence distinguish it.

Length $7 \frac{3}{4}$, breadth $2 \frac{1}{2}$ lines.

Maniototo, Taïeri.

One individual trom $\mathrm{Mr}$. J. H. Lewis.

\section{Group Anchomenidæ.}

\section{Dichrochile cordicolle, sp. n.}

Subdepressed, ovate-oblong, glossy black; tarsi and antennæ rufo piceous; the basal three joints of these latter, the knees, and tips of palpi rufescent.

Head large, minutely and irregularly wrinkled in front. Labrum deeply notched. Eyes prominent. Antenne elongate, 
reaching backwards to intermediate femora; basal three joints glabrous, the others pubescent, first stouter and rather longer than third, second about one third shorter than the following one. Thorax $1 \frac{1}{8}$ lines long by nearly $1 \frac{1}{2}$ broad, widest before the middle, gradually narrowed behind, posterior angles obtuse, apex widely incurved, base medially emarginate and obliquely rounded towards each side, lateral margins a little reflexed; the discoidal stria extends from base to apex, the basal fossæ are large; there is a curvate transverse impression in front, with some feeble longitudinal stria similar to those at the base. Elytra oblong, shoulders rounded and slightly narrowed, apices oblique; they have deep impunctate strie.

There are two seta on each side of the thorax, one at the lind angle and the other near the middle, and there are four on the hind margin of the last ventral segment of the female.

Mate.-Anterior tarsi with three dilated basal joints, each almost cordate, the first longest. Mandibles obtuse at extremity, the right one with a small blunt tooth on the inside, more evident in the other sex.

This is the largest species known to occur here. The thorax is quadrate-cordate. $D$. subopaca and $D$. ovicollis have dull elytra.

Length $5 \frac{3}{4}$, breadth $2 \frac{1}{8}$ lines.

Te Aroha.

Three examples from Mr. J. J. Walker.

\section{Anchomenus Walkeri, sp. n.}

Subdepressed, somewhat nitid, rufescent; legs, palpi, and antennæ testaceous.

Head oviform, longer than the thorax and almost as broad as that is; two large sulciform impressions extend from the occiput to the forehead, they are situated nearer to the centre than they are to the eyes; the sides, outside the deep stria which proceeds forwards from each eye, are slightly angulated at the point of antennal insertion; the genæ are broadly rounded. Labrum somewhat incurved. Mandibles elongate. Eyes rather small and but little prominent, distant from thorax. Antennoe elongate, slender, their third joint nearly twice the length of the second; they are finely pubescent, the basal two joints, however, are glabrous. Thorax as long as broad, widest before the middle, well rounded there, deeply sinuate behind, so that the acute posterior angles appear large and prominent; the base is truncate, the apex emarginate; the median furrow extends from the front and is a little 
expanded at the base; the fossæe are large and broad. Elytra ample, one-half longer than broad; shoulders rounded, the apex also rounded, so that the extremity of the hind body seems broad; their striæ are well marked, but the punctuation is indistinct; the suture is bent forwards at the apex, so as to form a carina in line with the sixth interstice; the apical sculpture is obsolete; there are three punctures on the third interstices.

Legs slender; basal joint of the anterior tarsi oblong, fourth small and cordiform, without lobes, and hardly the width of the long terminal one; intermediate joints short; claws simple. The palpi are similar in structure to those of Anchomenus.

The long, deep, interocular furrows, relatively small thorax, with large outstanding basal angles, and the rather large hind body, broadly rounded posteriorly, give this species a peculiar aspect. The discovery of the male, years hence perhaps, will probably cause its removal from Anchomenus; its natural position, however, should be between that genus and Tarastethus.

q. Length $2 \frac{1}{2}$, breadth 1 line.

Westport.

My unique specimen is another of Mr. J. J. Walker's interesting captures. I have much pleasure in attaching his name to it.

\section{Tarastethus simplex, sp. n.}

Body slightly nitid, piceous; head and thorax more rufescent than the hind body; legs red; palpi, antennæ, and tarsi paler.

Head with two erect setæ near each eye. Antennce gradually thickened towards the extremity, the basal three joints glabrous, second joint not much more than half the length of the third, eleventh oval. Eyes but little convex. Thorax slightly transverse, widely incurved in front, widest near the middle; its sides distinctly margined, moderately rounded, gradually narrowed behind, posterior angles rectangular; the disk is slightly convex, the central groove does not attain the front margin, there are no basal foveæ, and only indistinct sculpture near the hind margin. Elytra ovate-oblong, their sides gently curvate; they have fine impunctate striæ and simple interstices; the external, however, form fine carinæ near the apices.

The chief peculiarity consists in the entire absence of the usual thoracic fossæ. The hind body is more oblong and flatter 
than in the typical species (T. puncticollis, Sharp), so that the lateral margins are conspicuous throughout.

. Length 23 , breadth 1 line.

Port Chalmers.

A single individual, found by Mr. J. J. Walker.

Tarastethus lavicollis, sp. $\mathrm{n}$.

Nitid, black, legs and antennæ rufous, antennæ and palpi paler.

Head with a deep groove alongside each eye, the frontal impressions feebly punctured. Eyes convex. Thorax nearly as long as it is broad, base and apex truncate; it is widest before the middle, the sides are only moderately rounded and narrowed behind, the lateral margins are distinct, the posterior angles rectangular; the dorsal furrow does not extend to the base, where there is no apparent sculpture, and the usual fossæ are absent. Elytra ovate-oblong, rather wider than thorax at base, humeral angles obtuse, lateral margins somewhat explanate; they are punctate-striate, but the striæ outside the three sufural on each are very lightly impressed or obsolete near the base; the apical carinæe are well developed. Legs stout, posterior tibiæ slightly bent.

'The elytral sculpture is considerably finer than that of T. puncticollis, but more sharply impressed than in T. simplex, which, moreover, is a smaller and narrower insect.

. Length $3 \frac{1}{4}$, breadth $1 \frac{1}{4}$ lines.

Te Aroha.

One individual was found quite recently by $\mathrm{Mr}$. J.J. Walker.

Obs.-Zolus femoralis. This was described about ten years ago from a female found at Wellington. Lately I received a male from Mr.J. V. Hudson for identification, and Mr. J. J. Walker has given me one from Westport and another from Picton, all of which have been subjected to a careful scrutiny, without, however, detecting anything that would justify the separation of any one specimen from my type. 'The femora are usually clear testaceuus, sometimes the legs are wholly pale castaneous. The frontal foveæ on the head in some individuals extend as far as the back of the eyes. The punctuation near the base of the thorax, though feeble in the female, is quite distinct in the other sex. 'The thorax itself' is. actually as long as it is broad in some cases, but just perceptibly broader in others. All may be distinguished trom Sharp's $Z$. Helmsi by the fine, yet quite distinct, punctures of the elytral striæ.

[To be continued.] 